\title{
Nitrogen Fixation and Co-oxidation of Ethylene by a Methane-utilizing Bacterium
}

\author{
By J. A. M. DE BONT AND E. G. MULDER \\ Laboratory of Microbiology, Agricultural University, \\ Hesselink van Suchtelenweg 4, Wageningen, The Netherlands \\ (Received 22 November 1973; revised I6 February 1974)
}

\section{SUMMARY}

A methane-oxidizing bacterium, isolated from soil, was capable of fixing nitrogen. Nitrogenase activity could be assayed by acetylene reduction when the bacterium was growing on methanol but not when growing on methane, although ${ }^{15} \mathrm{~N}_{2}$ was fixed. Bacteria growing on methane co-oxidized ethylene but methanolgrowing cells did not. The organism was extremely sensitive to oxygen when dependent on $\mathrm{N}_{2}$ as nitrogen source, a consequence of the sensitivity of its nitrogenase towards oxygen.

\section{INTRODUCTION}

Nitrogen accumulates in soil exposed to natural gas (Schollenberger, 1930; Harper, 1939). Since methane is the main component of natural gas, and since this hydrocarbon had a similar effect on the nitrogen content of the soil (Davis, Coty \& Stanley, 1964; Coty, I967), methane-oxidizing bacteria, capable of fixing nitrogen, were thought to be responsible. Methane-oxidizing bacteria capable of growing in nitrogen-free medium were isolated. Nitrogen fixation was measured by Kjeldahl analyses of cultures incubated for periods of up to four months (Davis et al. 1964), whilst Coty (1967) performed an experiment with ${ }^{15} \mathrm{~N}_{2}$. As the isolated cultures also grew on nutrient agar, the purity of the cultures may be questioned. Whittenbury, Phillips \& Wilkinson (I970) isolated a strain of Methylosinus trichosporium from Coty's culture, which was able to reduce $25 \%$ of the acetylene present during an incubation period of 7 to 14 days. All of the other strains of methane-oxidizing bacteria tested reduced very little acetylene. We report here atmospheric nitrogen fixation by a recently isolated methane-oxidizing bacterium.

\section{METHODS}

Medium. The mineral-salts solution (MS medium), used throughout the investigation, contained the following salts in I l deionized water: $\mathrm{NaNO}_{3}, 2.0 \mathrm{~g} ; \mathrm{K}_{2} \mathrm{HPO}_{4}, 0.5 \mathrm{~g} ; \mathrm{KH}_{2} \mathrm{PO}_{4}$, $0.5 \mathrm{~g} ; \mathrm{MgSO}_{4} .7 \mathrm{H}_{2} \mathrm{O}, 0.2 \mathrm{~g} ; \mathrm{CaCl}_{2}, 0.0 \mathrm{I} 5 \mathrm{~g} ; \mathrm{FeSO}_{4} .7 \mathrm{H}_{2} \mathrm{O}$, 0.00I g; $\mathrm{CuSO}_{4} .5 \mathrm{H}_{2} \mathrm{O}, 5 \mu \mathrm{g}$; $\mathrm{H}_{3} \mathrm{BO}_{3}$, I0 $\mu \mathrm{g} ; \mathrm{ZnSO}_{4} \cdot 7 \mathrm{H}_{2} \mathrm{O}, 70 \mu \mathrm{g} ; \mathrm{MnSO}_{4} \cdot 5 \mathrm{H}_{2} \mathrm{O}$, I0 $\mu \mathrm{g} ; \mathrm{Na}_{2} \mathrm{MoO}_{4} \cdot 2 \mathrm{H}_{2} \mathrm{O}$, $100 \mu \mathrm{g}$; final $\mathrm{pH}, 6 \cdot 8$. For solid media $\mathrm{I} \cdot 5 \%$ agar was added to this nutrient solution.

Chemicals. Methane, ultra pure $\left(99.97 \%\right.$ ), and $\mathrm{CH}_{3} \mathrm{OCH}_{3}$, said to be $99.87 \%$ pure (see later), were obtained from the Matheson Co., and lithium hydroxypyruvate, $98 \%$ pure, from Sigma.

Isolation and growth of the bacterium. Garden soil was incubated at $28 \pm 2{ }^{\circ} \mathrm{C}$ under $10 \%$ methane in air. After 25 days, serial dilutions were made in MS medium, and after another 
4 weeks under $10 \%$ methane, material of the highest dilution showing growth was streaked on plates of MS agar. Well-developed colonies had grown on these plates after 3 weeks of incubation under $10 \%$ methane. Pure cultures, obtained after restreaking on the same medium, were then tested for methane-oxidizing capacity by growing the bacterium on slants of MS with and without methane. Weekly subcultures on slants of MS and slants of MS without nitrate were maintained in a desiccator in which the oxygen tension was lowered by flushing with nitrogen. Methane was injected through a Suba-seal mounted in a rubber stopper. Growth rate was measured in stirred $350 \mathrm{ml}$ side-arm flasks sealed with rubber stoppers, fitted with Suba-seal caps. Cell density was measured with an EEL nephelometer. During assays of acetylene reduction the cultures were stirred on a New Brunswick Scientific G Io gyrotory shaker at I50 rev./min.

Preparation of cell-free extract. Washed cells, suspended in $0.03 \mathrm{M}$-sodium phosphate buffer, were disrupted by ultrasonic disintegration. The extract was centrifuged and the supernatant fluid used for assay.

Enzyme assays. Hydroxypyruvate reductase (EC. I. I. I.29) and glyoxylate reductase (EC. I.I.I.26) were assayed in cuvettes ( $3 \mathrm{ml}$, light path $\mathrm{I} \mathrm{cm}$ ) containing $100 \mu \mathrm{mol}$ phosphate buffer, pH $6 \cdot 8,0 \cdot 4 \mu \mathrm{mol} \mathrm{NADH}$ and extract in a total volume of $3 \mathrm{ml}$. Lithium hydroxypyruvate $(2 \mu \mathrm{mol})$ or sodium glyoxylate $(2 \mu \mathrm{mol})$ were added and the decrease in extinction at $340 \mathrm{~nm}$ was measured against a blank containing buffer, NADH and extract.

Determination of protein. The Folin-Ciocalteu method was used (Herbert, Phipps \& Strange, I97I).

Gas-chromatographic analyses. Analyses were carried out at $50{ }^{\circ} \mathrm{C}$ with a Becker Multigraph type 407 gas chromatograph. Oxygen and nitrogen were measured by thermal conductivity using a $200 \mathrm{~cm} \times 4 \mathrm{~mm}$ column containing a I $3 \mathrm{X}$ molecular sieve (60-80 mesh). Hydrogen was used as carrier gas. Methane, dimethylether, and reduction of acetylene were assayed with a flame-ionization detector, using a $\mathrm{I} I 0 \mathrm{~cm} \times 4 \mathrm{~mm}$ Porapak R column with nitrogen as carrier gas.

${ }^{15} N$ analyses. Sample preparation was a modification (Akkermans, 197I) of the method of Faust (1967). Optical N-analyses were made with a ${ }^{15} \mathrm{~N}$ analyser (Statron NOI-4). The method of Ferraris \& Proksch (I 972) was used for calculating the ${ }^{15} \mathrm{~N}$ content.

\section{RESULTS}

\section{Description of the bacterium}

The isolate used, strain 4I, is a curved rod, motile in young cultures (Fig. I). On ageing of the culture, motility is lost and exospores are formed. In old cultures, only exospores and lysed cells were found (Fig. 2). Morphologically, the organism differs slightly from the isolates of Adamse, Hoeks, de Bont \& van Kessel (197I) and of Namsaraev \& Zavarzin (1972), but resembles one of the types described by Whittenbury et al. (I970) (Methylosinus sporium), and by Hazeu \& Steennis (1970) (Methylovibrio söhngenii). Purity of the strain was confirmed by microscopic examination and by streaking the culture onto various media for heterotrophs without obtaining growth. On plates of MS, uniform colony development was seen under methane. On slants of MS, without methane added, growth was just visible macroscopically and the bacteria present resembled strain $4 \mathrm{I}$ morphologically. A second transfer did not grow. Attempts to promote growth without methane by the addition of small quantities of yeast extract or peptone were unsuccessful. Higher concentrations of these and other substrates completely prevented growth of the first transfer. Strain $4 \mathrm{I}$ also utilized $\mathrm{CH}_{3} \mathrm{OH}$ for its development. No growth occurred with $\mathrm{C}_{2} \mathrm{H}_{2}, \mathrm{C}_{2} \mathrm{H}_{4}, \mathrm{C}_{2} \mathrm{H}_{6}, \mathrm{CH}_{3} \mathrm{OCH}_{3}$, 


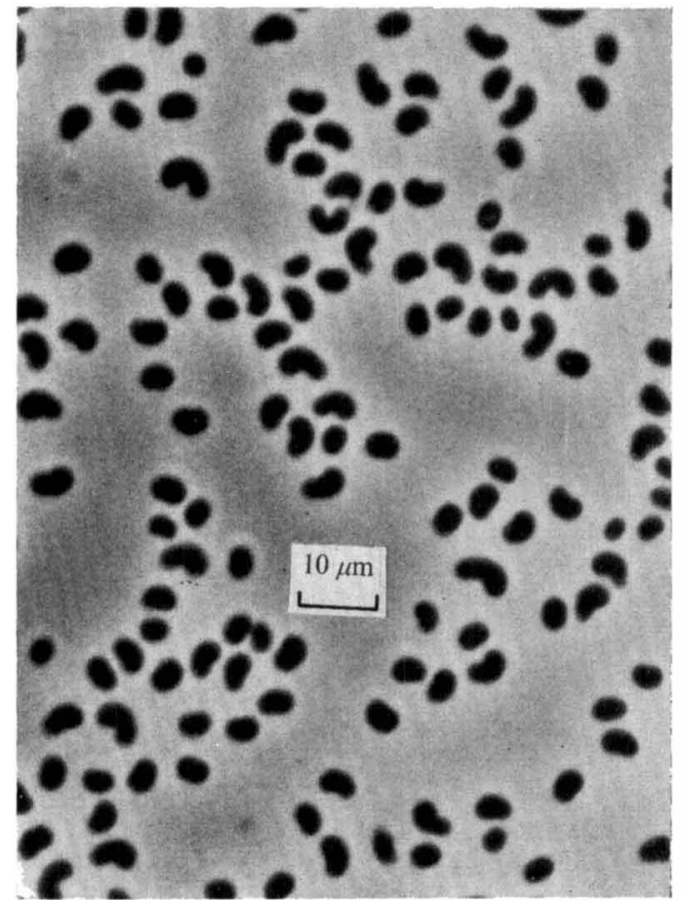

Fig. I

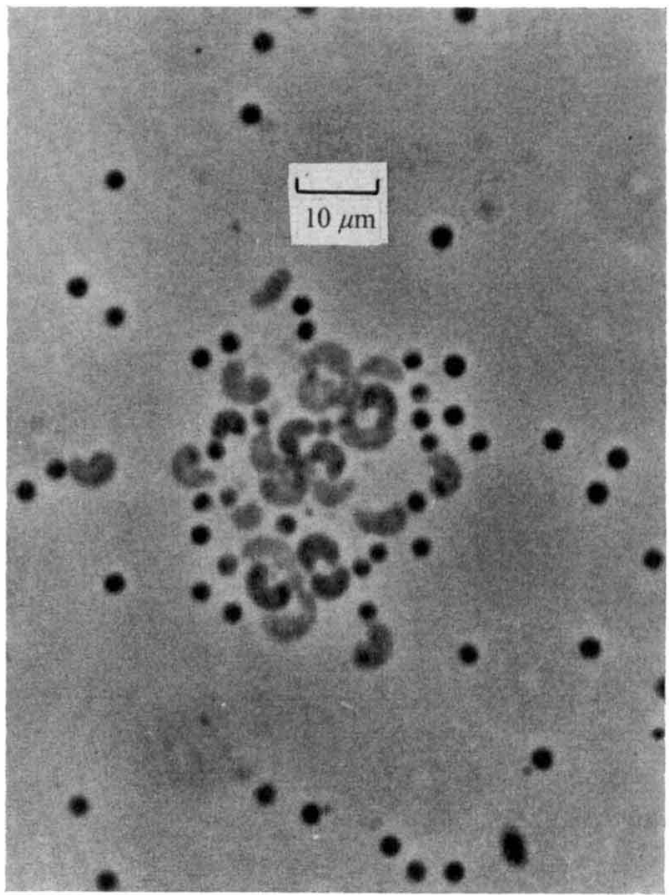

Fig. 2

Fig. I. Strain 41 from a five-day culture, grown on slants of MS under $10 \% \mathrm{CH}_{4}$.

Fig. 2. Strain 4I, exospores and lysed cells, from a three-week culture, grown on slants of MS under $10 \% \mathrm{CH}_{4}$.

$\mathrm{C}_{2} \mathrm{H}_{5} \mathrm{OH}$, glucose or acetate when added as potential substrates. No definite conclusions can be drawn for $\mathrm{CH}_{3} \mathrm{OCH}_{3}$. Our gas-chromatographic analysis of the contents of the cylinder containing $\mathrm{CH}_{3} \mathrm{OCH}_{3}(99.87 \%$ pure according to the supplier) indicated the presence of about $5 \%$ methane and approximately $0.5 \%$ of an unidentified compound among other minor impurities. Utilization of $\mathrm{CH}_{3} \mathrm{OCH}_{3}$ by methane-oxidizing bacteria has been reported and its role in the biological breakdown of methane discussed (Quayle, 1972).

Hydroxypyruvate reductase, the key enzyme of the serine pathway (Large \& Quayle, 1962), was present in strain $4 \mathrm{I}$. The activities were $2 \mathrm{I} \mu \mathrm{mol} \mathrm{NADH}$ oxidized $/ \mathrm{h} / \mathrm{mg}$ protein for hydroxypyruvate and $\mathbf{I} \cdot 5$ for glyoxylate.

\section{Growth in nitrogen-free medium}

If incubated without shaking, strain 4I grew slowly in MS medium under methane when nitrate was omitted from the medium. Acetylene-reduction assays for nitrogenase activity gave negative results. Growth in nitrogen-free medium was strongly promoted by lowering the oxygen tension, although no acetylene reduction was detected. When growing the organism in the same medium with methanol as substrate, ethylene production was clearly demonstrated after $10 \%$ acetylene had been introduced. The amount of ethylene formed could quantitatively account for the growth utilizing nitrogen fixation. The apparent difference in acetylene reduction may be due to the ability of $\mathrm{CH}_{4}$-grown cells to remove ethylene from the gas phase. After introduction of acetylene into such a gas phase, the ethylene 

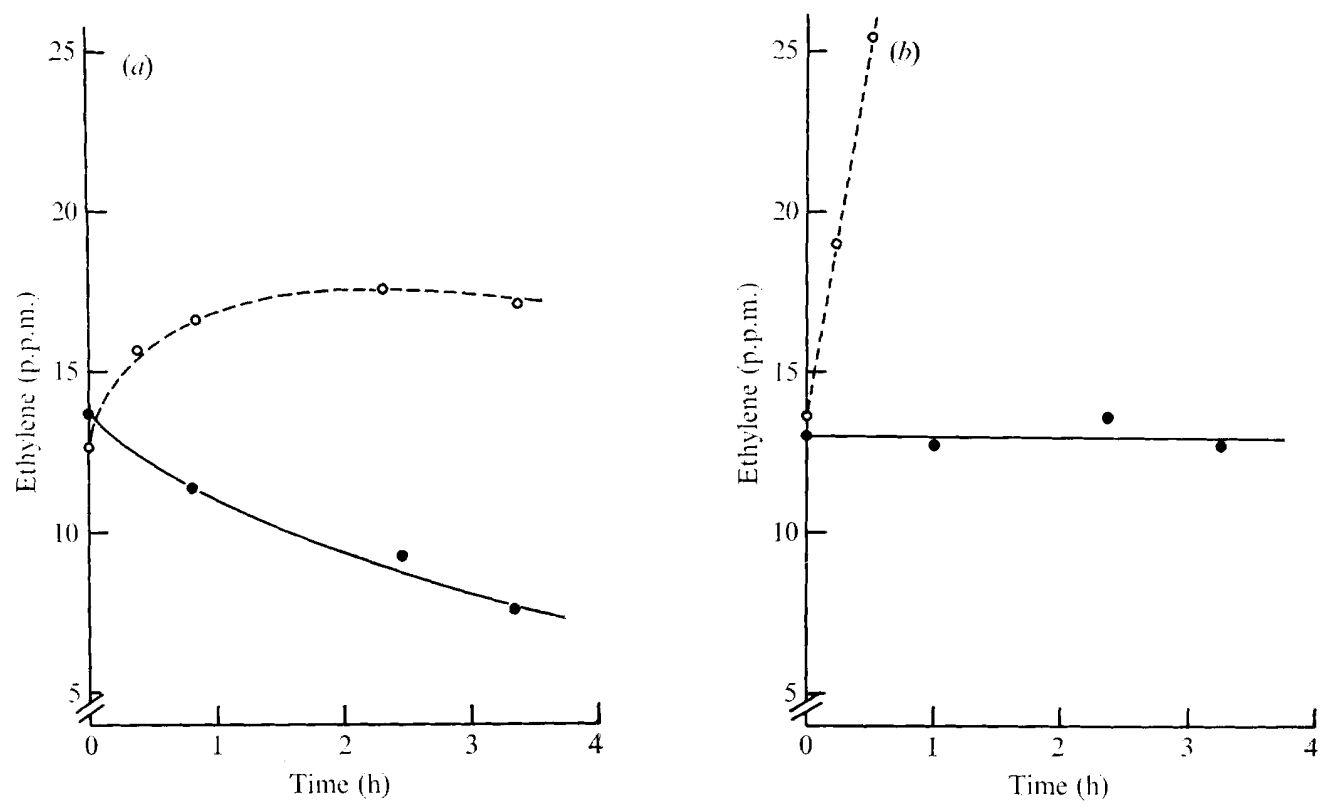

Fig. 3. Effect of strain 4I culture, growing in nitrogen-free MS with $10 \% \mathrm{CH}_{4}(a)$ and $0.1 \% \mathrm{CH}_{3} \mathrm{OH}$ (b), on ethylene ( 13 p.p.m.) in the absence (๑) and presence (O) of $10 \% \mathrm{C}_{2} \mathrm{H}_{2}$. Ethylene concentrations were measured in $50 \mathrm{ml}$ flasks with $10 \mathrm{ml}$ growing cultures. The gas phase in the flasks consisted of $5 \% \mathrm{O}_{2}, 10 \% \mathrm{CH}_{4}$ and $85 \% \mathrm{~N}_{2}(a)$ and $5 \% \mathrm{O}_{2}$ and $95 \% \mathrm{~N}_{2}(b)$ before the introduction of ethylene and acetylene.
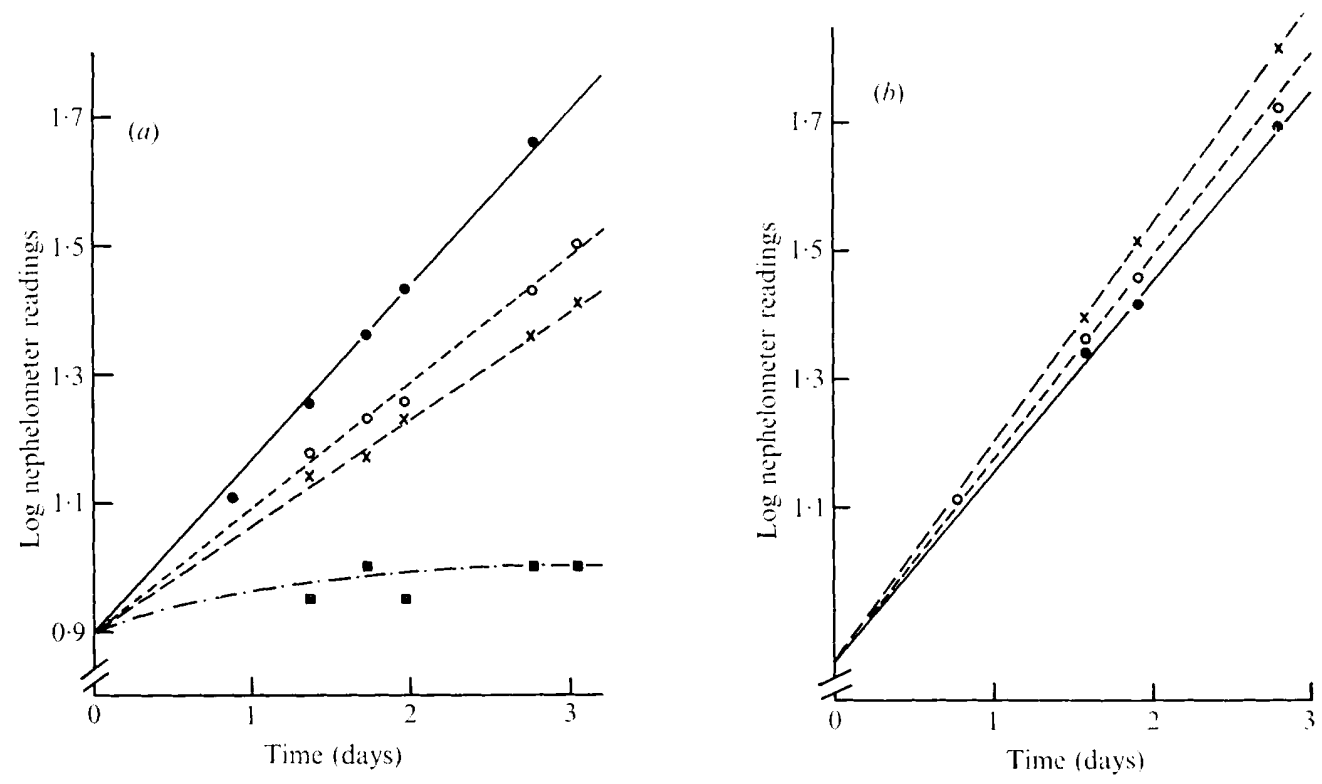

Fig. 4. Growth of strain $4 \mathrm{I}$ on $\mathrm{CH}_{4}$ as influenced by $\mathrm{O}_{2}$. Portions ( $\mathrm{IO} \mathrm{ml}$ ) of a culture growing logarithmically were injected into $350 \mathrm{ml}$ side-arm flasks containing $10 \% \mathrm{CH}_{4}$ and varying concentrations of $\mathrm{O}_{2}$ and $\mathrm{N}_{2} . \mathrm{O}_{2}$ consumption during the experiment was less than $2 \%$. (a) Growth in nitrate-free medium: $\bullet, 4 \% \mathrm{O}_{2} ; 0,6 \% \mathrm{O}_{2} ; \times, 8 \% \mathrm{O}_{2} ; \mathbf{m}$, II $\% \mathrm{O}_{2}$. (b) Growth with nitrate: -, $6 \% \mathrm{O}_{2} ; \mathrm{O}, \mathrm{II} \% \mathrm{O}_{2} ; \times, 15 \% \mathrm{O}_{2}$. 


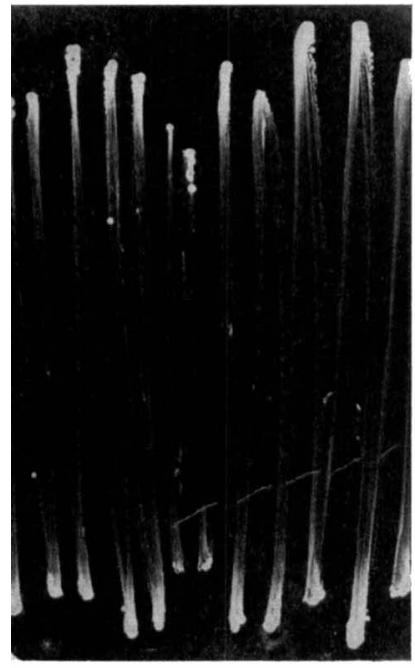

Fig. 5

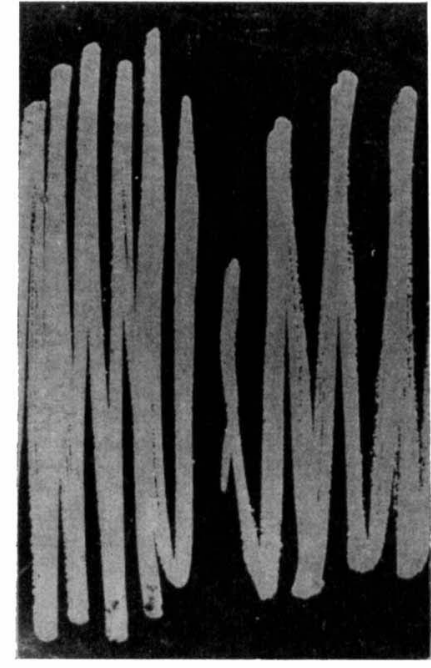

Fig. 6

Fig. 5. Growth of strain $4 \mathrm{I}$ on nitrogen-free MS agar medium under $20 \% \mathrm{O}_{2}, \mathrm{IO} \% \mathrm{CH}_{4}$ and $70 \%$ $\mathrm{N}_{2}$ after 3 weeks of incubation, showing sparse growth except at the edges of the streaks.

Fig. 6. Growth of strain $4 \mathrm{I}$ on nitrogen-free MS agar medium under $5 \% \mathrm{O}_{2}, \mathrm{IO}_{\%} \mathrm{CH}_{4}$ and $85 \% \mathrm{~N}_{2}$ after 3 weeks of incubation.

concentration remained at the same level (Fig. $3 a$ ). Cells grown on methanol did not affect ethylene production (Fig. $3 b$ ).

\section{Effect of oxygen}

Growth of strain 4I in liquid MS medium with methane was little influenced by oxygen tensions of between 4 and $20 \%$. On nitrogen-free medium, however, increasing the oxygen tension severely reduced growth (Fig. $4 a, b$ ). Similar phenomena were observed when the bacterium was grown on agar plates of MS under methane. Colony size after three weeks of incubation was not influenced by varying the oxygen tension. But when nitrogen-free MS was used, the effect of oxygen became apparent. Under $20 \%$ oxygen only meagre growth developed. Growth was better in restricted areas of such a plate (Fig. 5). Incubation in $5 \%$ oxygen allowed normal development on nitrogen-free medium (Fig. 6). That the sensitivity towards oxygen is directly related to the nitrogenase activity was shown by measuring acetylene reduction by methanol-grown cells exposed to varying oxygen tensions (Fig. 7). In a subsequent experiment, nitrogenase was inactivated by exposure to $28 \%$ oxygen in the atmosphere and activity restored after lowering the oxygen tension (Fig. 8).

The behaviour of strain $4 \mathrm{I}$ towards oxygen (Fig. $4 a, b$ ) resembles that of certain Azotobacter species (Dalton \& Postgate, I969). Both types of bacteria are highly sensitive to moderate concentrations of oxygen when depending on $\mathrm{N}_{2}$ as nitrogen source, but insensitive to oxygen in the presence of combined nitrogen. The poor growth of strain 4I under methane on a nitrogen-free agar medium when exposed to air, in contrast to normal growth at decreased oxygen tension (Figs. 5 and 6), agrees with a similar behaviour of the nitrogenfixing Derxia gummosa (Hill, I971). In both organisms the nitrogenase system does not function when the agar plates are kept in air, but normal nitrogen fixation occurs at reduced oxygen pressure. Sporadically occurring nitrogen-fixing colonies may arise on plates exposed to air as a result of locally occurring clumps of the inoculated organism. Oxygen supply to 


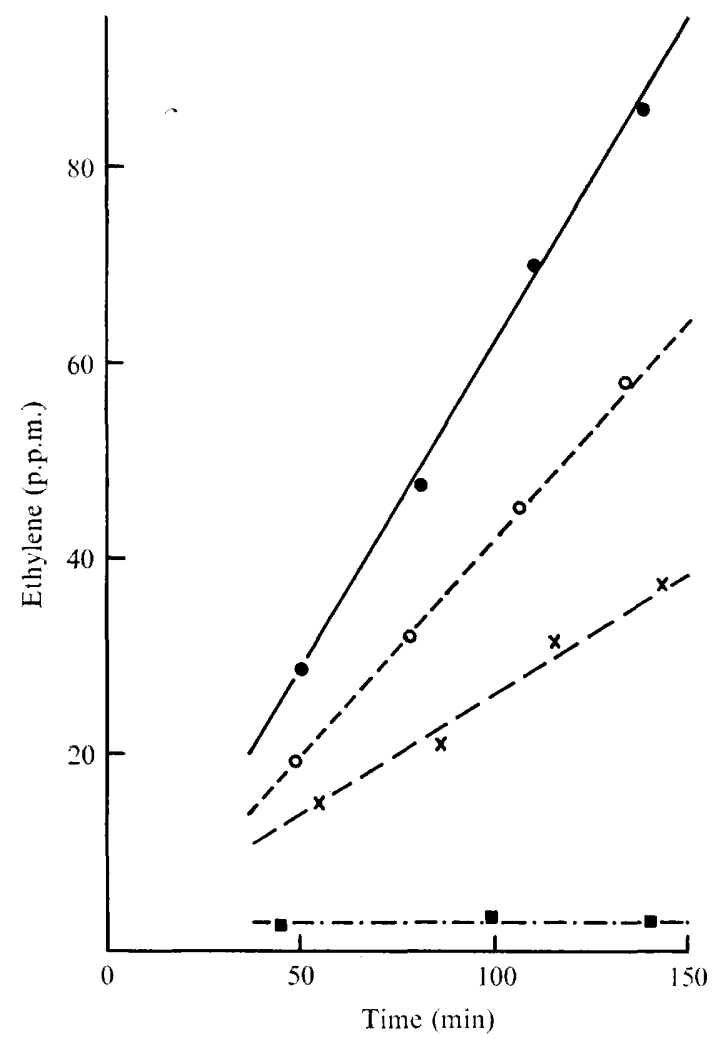

Fig. 7

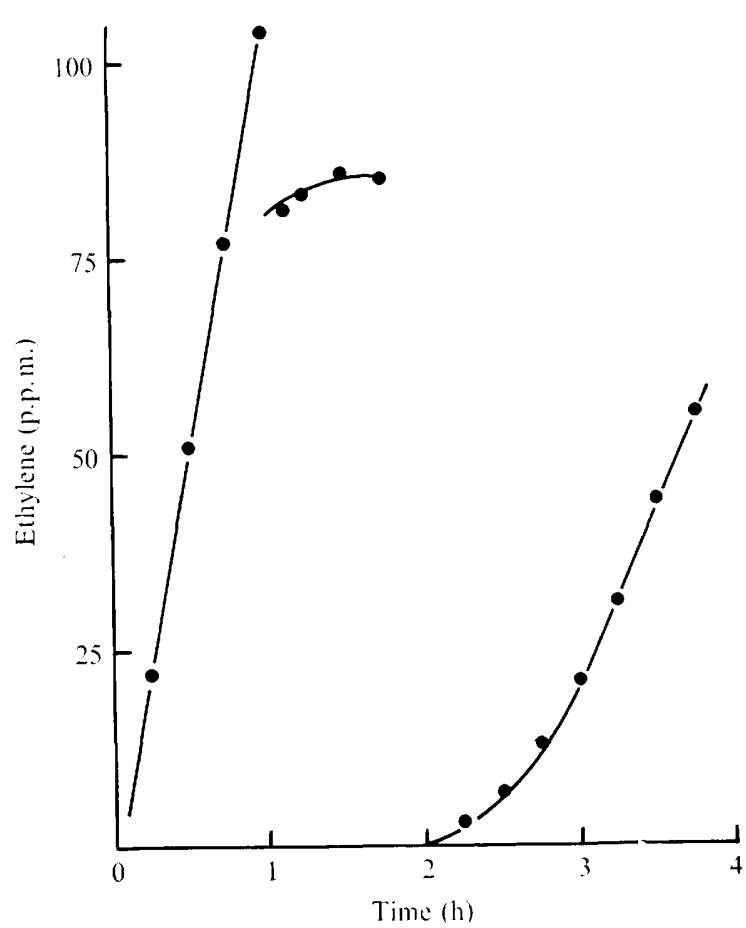

Fig. 8

Fig. 7. Acetylene reduction as influenced by $\mathrm{O}_{2}$. Portions ( $10 \mathrm{ml}$ ) of a culture growing under reduced $\mathrm{O}_{2}$ tension on $\mathrm{CH}_{3} \mathrm{OH}$ in nitrogen-free MS were injected into $50 \mathrm{ml}$ flasks containing $10 \%$ $\mathrm{C}_{2} \mathrm{H}_{2}$ and different levels of $\mathrm{O}_{2}$ and $\mathrm{N}_{2} . \bullet, 4.4 \% \mathrm{O}_{2} ; \mathrm{O}, 6.3 \% \mathrm{O}_{2} ; \times, 10.2 \% \mathrm{O}_{2} ; \mathbf{m}, 18.0 \% \mathrm{O}_{2}$.

Fig. 8. Reactivation of nitrogenase, inactivated after exposure to high $\mathrm{O}_{2}$ concentration. Thirty $\mathrm{ml}$ of a culture growing under reduced $\mathrm{O}_{2}$ tension on $\mathrm{CH}_{3} \mathrm{OH}$ in nitrogen-free MS was injected into a I $00 \mathrm{ml}$ flask containing $10 \% \mathrm{C}_{2} \mathrm{H}_{2}, 4.5 \% \mathrm{O}_{2}$ and $85.5 \% \mathrm{~N}_{2}$, and ethylene production measured for I h. Excess $\mathrm{O}_{2}$ was then injected. After releasing pressure, the $\mathrm{O}_{2}$ concentration was $28 \%$. After 45 min the flask was opened, flushed with $\mathrm{N}_{2}$, and $\mathrm{C}_{2} \mathrm{H}_{2}$ was restored to $10 \% ; \mathrm{O}_{2}$ tension was now $3.5 \%$.

cells in the interior of the clumps would be lowered, so the development of the nitrogenase system would become possible. Nitrogen-fixing colonies are often seen at the end of an inoculation streak of a nitrogen fixer where accumulation of cells easily occurs.

A response similar to that of nitrogenase of strain 4I towards oxygen (Figs. 7 and 8 ) has been found for nitrogenase of Azotobacter chroococcum (Postgate, I97I; Drozd \& Postgate, I970).

\section{Nitrogen fixation on methane}

Evidence for nitrogen fixation by strain 4I when growing with methane was obtained with ${ }^{15} \mathrm{~N}_{2}$ (Table I). The bacteria were grown in nitrogen-free medium at reduced oxygen tension. In early logarithmic phase, $70 \mathrm{ml}$ of the culture was injected into a $250 \mathrm{ml}$ flask. Another $70 \mathrm{ml}$ was used as a blank. The gas phase in the flask consisted of $20 \%$ methane, $5 \%$ oxygen and $75 \%$ nitrogen. The nitrogen gas was enriched with $10 \%{ }^{15} \mathrm{~N}$. After $8 \mathrm{~h}, 40 \mathrm{ml}$ of the 
Table $1 .{ }^{15} N_{2}$ fixation by strain $4 \mathrm{I}$

\begin{tabular}{|c|c|c|c|c|c|c|}
\hline & \multirow{2}{*}{$\begin{array}{c}\text { Time of } \\
\text { incubation }(h)\end{array}$} & \multirow{2}{*}{$\begin{array}{l}\text { Nephelometer } \\
\text { readings }\end{array}$} & \multirow{2}{*}{$\begin{array}{l}\text { Suspension } \\
\quad(\mathrm{ml})\end{array}$} & \multirow{2}{*}{$\begin{array}{l}\text { Nitrogen/ } \\
\text { sample } \\
(\mu \mathrm{g})\end{array}$} & \multicolumn{2}{|c|}{ Atom $\%{ }^{15} \mathrm{~N}$} \\
\hline & & & & & Measured & Theoretical* \\
\hline Blank & 0 & 9 & 70 & 180 & 0.37 & - \\
\hline Sample I & 8 & 13 & 40 & I 34 & $1 \cdot 84$ & 3.45 \\
\hline Sample 2 & 23 & 24 & 30 & 225 & $5 \cdot 13$ & $6 \cdot 62$ \\
\hline
\end{tabular}

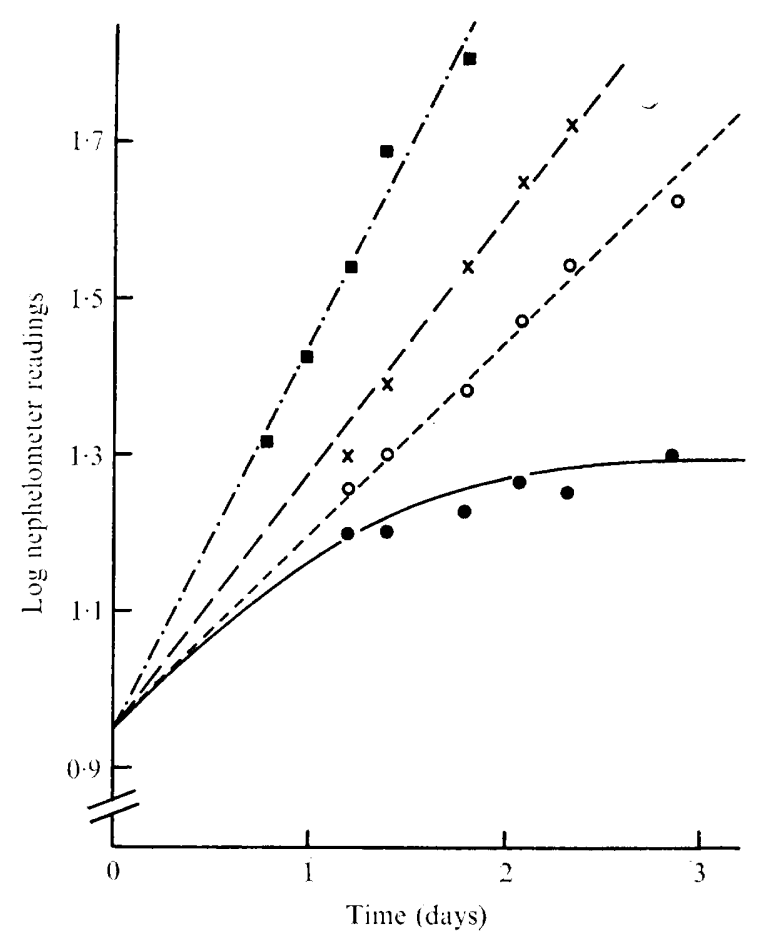

Fig. 9. Effect of $\mathrm{N}_{2}$ on the growth of strain $4 \mathrm{I}$ in nitrogen-free MS medium with methane. Portions ( $10 \mathrm{ml}$ ) of a culture growing in nitrogen-free MS under $\mathrm{CH}_{4}$ were injected into $350 \mathrm{ml}$ side-arm flasks with $6 \% \mathrm{O}_{2}, 10 \% \mathrm{CH}_{4}$ and different concentrations of $\mathrm{N}_{2}$ and $\mathrm{He}$ to $1 \mathrm{~atm} . \mathbf{0}, 5.7 \% \mathrm{~N}_{2}$; $0,11.9 \% \mathrm{~N}_{2} ; \times, 20.4 \% \mathrm{~N}_{2} ; \boldsymbol{m}, 80 \cdot 6 \% \mathrm{~N}_{2}$.

sample was withdrawn and the gas phase inside the flask was brought back to atmospheric pressure with helium. The second sample was taken after the culture had grown for $23 \mathrm{~h}$.

After correcting for the blank, the excess ${ }^{15} \mathrm{~N}$ percentages of $\mathrm{I} \cdot 47$ and 4.76 in the culture were of the same comparative magnitude as values of 3.08 and $6 \cdot 25$, respectively, calculated by using nephelometer readings as a measure for nitrogen assimilation in growing cultures. The low value for the first sample could be due to dissolved nitrogen gas in the culture when it was placed under the gas phase enriched with ${ }^{15} \mathrm{~N}_{2}$.

Additional evidence for nitrogen fixation was obtained by growing strain $4 \mathrm{I}$ in nitrogenfree medium under, initially, $10 \%$ methane and $6 \%$ oxygen, with helium/nitrogen gas mixtures to give different nitrogen pressures. Fig. 9 shows that under these conditions, growth 
increased as the $\mathrm{N}_{2}$ increased. From this experiment, it was estimated that the $K_{m}$ value for $\mathrm{N}_{2}$ will be approximately $\mathrm{I} 6 \%$. This value is in agreement with $K_{m}$ constants found for crude extracts of other nitrogen-fixing bacteria (Parejko \& Wilson, I97I).

\section{DISCUSSION}

Strain $4 \mathrm{I}$ has the physiological characteristics of a methane-oxidizing bacterium. Only methane and methanol support growth. The presence of hydroxypyruvate reductase indicated that synthesis of cellular material proceeded by the serine pathway (Lawrence \& Quayle, 1970).

Measurement of nitrogen fixation by methane-oxidizing bacteria during prolonged periods of incubation (Davis et al. 1964 ) is open to criticism. Uptake of ${ }^{15} \mathrm{~N}_{2}$ by one of the isolated strains (Coty, 1967) provided more convincing evidence of the nitrogen fixation. The fact that the isolated culture grew on nutrient agar suggests that it was not pure. This was corroborated by the isolation of a strain of Methylosinus trichosporum from Coty's culture (Whittenbury et al. 1970). Upon exposure to an atmosphere containing $4.4 \%$ methane and $\mathrm{I} \cdot 8 \%$ acetylene for 7 or I4 days, this isolate had reduced the acetylene concentration by $25 \%$. It is unknown whether the disappearance of acetylene was due to co-oxidation of acetylene or to reduction of this compound to ethylene; data on ethylene production were not reported. From this result no definite conclusions can be drawn concerning the nitrogenfixing ability of the organism, because only short-term exposure times should be used in the acetylene-reduction technique for assessing presence of nitrogenase (Hardy, Burns \& Holsten, I973).

Our results demonstrate fixation of atmospheric nitrogen by the methane-oxidizing strain 4I. Nitrogenase activity, measured by acetylene reduction, could only be detected when the bacteria were growing on methanol without combined nitrogen. Co-oxidation of ethylene by cultures grown under methane and acetylene may explain the apparent lack of ethylene production from acetylene. Alternatively, acetylene may block methane oxidation and thus prevent the supply of ATP to nitrogenase.

The authors are much indebted to Dr A. D. Adamse for his continuous interest and criticism during the course of the investigation and in the preparation of the manuscript. We thank Dr A. D. L. Akkermans for his stimulating discussions and for performance of the ${ }^{15} \mathrm{~N}$ analyses. Support for the research has come in part from grants of the N.V. Nederlandse Gasunie and the V.E.G. Gasinstituut.

\section{REFERENCES}

Adamse, A. D., Hoeks, J., de Bont, J. A. M. \& van Kessel, J. F. (I97I). Microbial activities in soil near natural gas leaks. Archiv für Mikrobiologie 83, 32-5I.

AKKermans, A. D. L. (1971). Nitrogen fixation and nodulation of Alnus and Hippophae under natural conditions. Thesis, University of Leiden, The Netherlands.

CотY, V. F. (1967). Atmospheric nitrogen fixation by hydrocarbon-oxidizing bacteria. Biotechnology and Bioengineering 9, 25-32.

Dalton, H. \& Postgate, J. R. (1969). Effect of oxygen on growth of Azotobacter chroococcum in batch and continuous cultures. Journal of General Microbiology 54, 463-473.

Davis, J. B., Coty, V. F. \& Stanley, J. P. (1964). Atmospheric nitrogen fixation by methane-oxidizing bacteria. Journal of Bacteriology 88, 468-472.

Drozd, J. \& Postgate, J. R. (1970). Interference by oxygen in the acetylene-reduction test for aerobic nitrogen-fixing bacteria. Journal of General Microbiology 6o, 427-429.

FAUST, H. (1967). Probenchemie ${ }^{15} \mathrm{~N}$ markierter Stickstoffverbindungen im Mikro- bis Nanomolbereich für die emissionsspektrometrische Isotopenanalyse. Isotopenpraxis 3, I00-103. 
Ferraris, M. M. \& ProksCh, G. (1972). Calibration methods and instrumentation for optical ${ }^{15} \mathrm{~N}$ determinations with electrodeless discharge tubes. Analytica chimica acta 59, 177-185.

HARDY, R. W. F., Burns, R. C. \& Holsten, R. D. (1973). Applications of the acetylene-ethylene assay for measurement of nitrogen fixation. Soil Biology and Biochemistry 5, 47-8I.

HARPER, H. J. (1939). The effect of natural gas on the growth of micro-organisms and the accumulation of nitrogen and organic matter in the soil. Soil Science 48, 46I-466.

HAZEU, W. \& SteENNIS, P. J. ( 1970 ). Isolation and characterization of two vibrio-shaped methane-oxidizing bacteria. Antonie van Leeuwenhoek 36, 67-72.

Herbert, D., Phipps, P. J. \& Strange, R. E. (1971). Chemical analysis of microbial cells. In Methods in Microbiology, vol. 5B, pp. 209-344. London and New York: Academic Press.

HILL, S. (1971). Influence of oxygen concentrations on the colony type of Derxia gummosa grown on nitrogenfree media. Journal of General Microbiology 67, 77-83.

LARGE, P. J. \& QuAYLE, J. R. (1962). Microbial growth on CI compounds. V. Enzyme activities in extracts of Pseudomonas AMI. Biochemical Journal 87, 386-396.

LAWRENCE, A. J. \& QUAYLE, J. R. (1970). Alternative carbon assimilation pathways in methane-utilizing bacteria. Journal of General Microbiology 63, 37I-374.

Namsaraev, B. B. \& Zavarzin, T. A. (1972). Trophic relationships in a methane-oxidizing culture. In Mikrobiologiya 4I, pp. 999-1006, English translation pp. 887-892. New York: Plenum Publishing Corp.

Parejko, R. A. \& Wilson, P. W. (197I). Kinetic studies on Klebsiella pneumoniae nitrogenase. Proceedings of the National Academy of Sciences of the United States of America 68, 2016-2018.

Postgate, R. (197I). Biochemical and physiological studies with free-living, nitrogen-fixing bacteria. Plant and Soil, Special Volume 197I, 55I-559.

QUAYLE, J. R. (I972). The metabolism of one-carbon compounds by microorganisms. Advances in Microbial Physiology 7, II9-203.

SChollenderger, C. J. (1930). Effect of leaking natural gas upon the soil. Soil Science 29, 26I-266.

Whittendury, R., Phillips, K. C. \& Wilkinson, J. F. (I970). Enrichment, isolation and some properties of methane-utilizing bacteria. Journal of General Microbiology 6r, 205-21 8. 